Egyptian Journal of Aquatic Biology \& Fisheries

Zoology Department, Faculty of Science,

Ain Shams University, Cairo, Egypt.

ISSN $1110-6131$

Vol. 23(5): 193 - 215 (2019)

www.ejabf.journals.ekb.eg

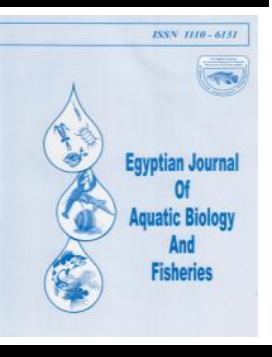

\title{
Cadmium Toxicity-Induced Oxidative Stress and Genotoxic Effects on Nile tilapia (Oreochromis niloticus L.) Fish: The Protective Role of Fenugreek (Trigonella foenum-graecum) Seeds
}

\author{
Wafaa T. Abbas ${ }^{1}$, Mohammad M. N. Authman ${ }^{*}$, Doaa A. Darwish ${ }^{2}$, \\ Amany M. Kenawy ${ }^{1}$, Iman M.K. Abumourad ${ }^{1}$ and Taghreed B. Ibrahim ${ }^{1}$ \\ 1- Hydrobiology Department, National Research Centre, Dokki 12622, Giza, Egypt. \\ 2- Molecular Biology Department, National Research Centre, Dokki 12622, Giza, Egypt \\ *Corresponding Author: mm.authman@nrc.sci.eg; mmauthman@yahoo.com
}

\section{ARTICLE INFO \\ Article History: \\ Received: Sept. 11, 2019 \\ Accepted: Nov. 28, 2019 \\ Online: Dec. 2019}

\section{Keywords:}

Fenugreek seeds

Cadmium toxicity

Oreochromis niloticus

Biochemical

Antioxidants

Histopathology

\section{ABSTRACT}

The present work was designed to study the alleviation influence of fenugreek (Trigonella foenum-graecum) on Nile tilapia (Oreochromis niloticus L.) experimentally exposed to Cd toxicity. A total of 400 fish were randomly divided into 10 groups (G1-G10) and fish was exposed to sublethal dose of $\mathrm{Cd}$ and fed on fenugreek seeds (crude or extract), individually or in combination for 45 days. The results showed that $\mathrm{Cd}$ exposure increased significantly the serum total protein, albumin, globulin, alanine aminotransferase (ALT), glucose and cholesterol, whereas aspartate aminotransferase (AST) and uric acid were significantly decreased. Also, hepatic protein content, catalase (CAT), superoxidase dismutase (SOD) and glutathione-S-transferase (GST) increased significantly due to $\mathrm{Cd}$ exposure. Additionally, $\mathrm{Cd}$ induced significantly metallothionein-gene (MT) expression and increased $\mathrm{Cd}$ concentrations in different fish tissues. Feeding on fenugreek extract $1 \%$ and $3 \%$ has reduced some $\mathrm{Cd}$-induced biochemical and antioxidant alterations; however, it decreased ALT, AST and uric acid in serum and also reduced CAT and SOD activities. Fenugreek extract induced $M T$ up-regulation and decreased $\mathrm{Cd}$ accumulation in some fish tissues. Although, feeding on fenugreek extract with $\mathrm{Cd}$ exposure somewhat reduced the histopathological changes compared to Cd-exposed group, some pathological changes were observed in fenugreek-fed groups especially in high concentrations. It could be concluded that fenugreek seeds extract at level of $1 \%$ could be used as feed supplement to Nile tilapia to alleviate some toxic effects of $\mathrm{Cd}$ and reduction of $\mathrm{Cd}$ accumulation in fish tissues (especially muscle) in such a way to help fish in facing Cd toxicity and reducing the public health hazard.

\section{INTRODUCTION}

Aquaculture had been known in Egypt since the old Egyptian eras (Shaalan et al., 2018). The present aquaculture is depended mainly on the water from agricultural drainage channels where aquaculture projects are not allowed to use irrigation or Nile water (Soliman, 2017). Drainage water was reported as contaminated with agrochemicals, industrial effluents, and domestic sewage (Khallaf et al., 2003). Accordingly, this pollution shows deleteriously effects on farmed fish quality (FAO, 2014) and may have negative effects on the health of human who consume the 
polluted fish (Mur, 2014). Drainage water may contains high concentrations of runoffderived fertilizers, pesticides, heavy metals, and so on (Authman et al., 2012). Among most of heavy metal contaminants released into the aquatic environment, cadmium (Cd) which has been documented as one of the greatest toxic heavy metal that causes adverse effects on aquatic organisms (Shah et al., 2017). Major sources of Cd are industrial and agrochemical wastes (e.g., nickel cadmium batteries manufacturing plants, lead mining and processing units, sewage sludge and fertilizers (i.e. phosphate) that contain high-level of $\mathrm{Cd}$, pigments, ceramics, plastics, glasses, vehicle tires and other synthetics) which discharge into surface water bodies and then be taken by aquatic organisms (Zang and Bolger, 2014; El-Kady and Abdel-Wahhab, 2018). Cadmium has been found to be accumulated in high concentrations in various organs such as intestine, kidney, liver, gills, muscles, and reproductive organs of Nile tilapia, O. niloticus (Otludil et al., 2017). It causes biochemical, physiological, and oxidative stress alterations, anemia, serious histopathological changes and so on (AbdelTawwab and Wafeek, 2014; Al-Asgah et al., 2015; Abdel-Tawwab and Wafeek, 2017; Otludill et al., 2017) and had carcinogenic and endocrine-damaging properties (Bobocea et al., 2008). Cadmium has also adverse effects on osmoregulation, survival, growth and reproduction (Kim et al., 2004; Szczerbik et al., 2006), damage fish health and aquatic ecosystems (Zhou et al., 2017). So, there is an urgent need to develop low-cost, sustainable and effective methods to mitigate its toxic effect on fish. Therefore, there is a need for unusual methods to managing heavy metals toxicity that are appropriate to many toxicants and many species (Sayed et al., 2015).

Recently, many studies have reported using either plants or plant extracts in aquaculture not only as feed additives but also as chemotherapeutics (Wang et al., 2015; Abdel-Tawwab, 2016), as they contains a wide variety of chemical compounds and nutrients (Chang, 2000). It is worth to mention that plants can also induced antioxidant enzymes such as catalase, superoxide dismutase, glutathione Stransferase, and peroxidases, which play an important role in detoxification and removal of toxicity-induced reactive oxygen species (Guardiola et al., 2017; AbdelTawwab et al., 2018). In this regard, an interest in using fenugreek (Trigonella foenum graecum L.) [FN], in fish diets has gained attention in recent years (Mostafa et al., 2009; Mehboob et al., 2017; Roohi et al., 2017). The leaves of FN are used in diets as green leafy vegetables, which is rich in vitamins and minerals (Srinivasan, 2006; Roohi et al., 2017) and its seeds are used for medication in different countries for aphrodisiac effects, tonic and carminative (Xue et al., 2007). Fenugreek has been shown to have many biological activities as anti-inflammatory, anti-carcinogenic potential, potential allergens, antibacterial, anti-diabetic and antioxidant activity (Belguith-Hadriche et al., 2013; Mehboob et al., 2017).

In Egypt and worldwide, Nile tilapia, Oreochromis niloticus is the main farmed fish owing to its high delicacy by a huge number of people and high market value (El-Sayed, 2006). Moreover, Nile tilapia, O. niloticus has been used in major laboratory; field and toxicological researches (Authman et al., 2012). Several studies were conducted on the use of $\mathrm{FN}$ as a natural feed additive to improve growth performance, enhance disease resistance and immunity of Nile tilapia (Mostafa et al., 2009; Mehboob et al., 2017; Roohi et al., 2017) but there are no studies reporting the role of $\mathrm{FN}$ in ameliorating the toxic effects and chelating of $\mathrm{Cd}$ in fish. So, the purpose of the present work was: 1) to investigate the FN chelating ability of $\mathrm{Cd}$ accumulated in fish tissues, and 2) to determine the role of FN in the amelioration of the biochemical, histopathological and antioxidant alterations induced in $O$. niloticus 
by cadmium exposure. This study may give the feasible solution to overcome pollution problems in fish farming.

\section{MATERIALS AND METHODS}

\section{Fish}

Apparently healthy all-male Nile tilapia, O. niloticus (30-40 g body weight; $n=$ 400) were obtained from a commercial fish farm at Kafr El-Sheik governorate, Egypt, and were then transported to the Hydrobiology Department, National Research Centre, Dokki. Fish were kept in 120 L glass aquaria under laboratory conditions for 2 weeks for acclimatization, during which fish were fed on a commercial 5-mm floating dry diet pellets (Skretting Egypt, Hendrix) [35\% total crude protein, 5.8\% fat (ether extract), $3.5 \%$ crude fibers and $4100 \mathrm{Kcal}$ digestible energy] at feeding level of $2 \%$ of body weight per day. To reduce impurities from metabolic wastes, the water was changed twice a week.

\section{Fenugreek (FN) seeds}

FN (T. foenum graecum) seeds were obtained from a commercial market (Egypt). Crude crushed seeds and alcoholic extract of FN seeds were prepared. For crude crushed seeds: FN seeds were firstly washed, dried and crushed, whereas for alcoholic extract of FN seeds: $1 \mathrm{~kg}$ of crushed FN was soaked in double volume of absolute ethanol in a stoppered container for five days, shaked more than one time per each day, filtered and evaporated by a rotary evaporator, then left for complete dryness and weighed (Azwanida, 2015).

Fish diets

A commercial 5-mm floating dry pellets (35\% total crude protein) was firstly crushed, mixed with the appropriate ratios of crude crushed seeds $(0.0,2.5$ and 5.0\%) or its alcoholic extract $(0.0,1.0$ and $3.0 \%)$, and wet with $100 \mathrm{ml}$ water to make a paste. The pastes were made again into pellets, and the wet pellets allowed to dry in the open air (protected from bacteria and fungi infection by covering) and then stored at $4^{\circ} \mathrm{C}$ until use.

\section{Chemicals}

Cadmium Chloride $\left[\mathrm{CdCl}_{2}\right.$; (purity $>95 \%$ and $\mathrm{Mw}$ : 183.32] was obtained from Laboratory Rasayan Fine-Chem LTd. (Haryana, India). A stock solution of Cd was freshly prepared by dissolving $\mathrm{CdCl}_{2}$ in deionized water at a concentration of 1000 $\mathrm{mg} \mathrm{L} \mathrm{L}^{-1}$. Serum total protein, glucose, aspartic aminotransferase (AST), alanine aminotransferase (ALT), albumin, cholesterol, and uric acid were estimated using commercial biochemical kits bought from Spectrum-Diagnostics Co., Egypt. All other chemicals were of analytical grade.

\section{Experimental design}

After the fish acclimation, fish were randomly allocated into 10 groups, each group containing 40 fish (20 fish/glass aquarium; two replicates). The $1^{\text {st }}$ group (G1) was the control which received a commercial fish food without any additives. The $2^{\text {nd }}$ group (G2) received a commercial fish food without any additives and subjected to $1 / 10 \mathrm{LC}_{50}$ of cadmium toxicity $\left(1.5 \mathrm{mg} \mathrm{Cd} \mathrm{L}^{-1}\right.$ of $\mathrm{CdCl}_{2}$ ) according to Garcia-Santos et al. (2006). The $3^{\text {rd }}$ group (G3) was fed on crushed crude FN seeds-supplemented diet at a concentration of $2.5 \%$. The $4^{\text {th }}$ group (G4) was fed on crushed crude FN seeds-supplemented diet at a concentration of $2.5 \%$ and subjected to cadmium toxicity ( $1.5 \mathrm{mg} \mathrm{Cd} \mathrm{L}^{-1}$ of $\mathrm{CdCl}_{2}$ ). The $5^{\text {th }}$ group (G5) was fed on crushed crude FN seedssupplemented diet at a concentration of $5 \%$. The $6^{\text {th }}$ group (G6) was fed on crushed crude FN seeds-supplemented diet at a concentration of 5\% and subjected to cadmium 
toxicity $\left(1.5 \mathrm{mg} \mathrm{Cd} \mathrm{L}{ }^{-1}\right.$ of $\left.\mathrm{CdCl}_{2}\right)$. The $7^{\text {th }}$ group $(\mathrm{G} 7)$ was fed on alcoholic extract of FN seeds-supplemented diet at a concentration of $1 \%$. The $8^{\text {th }}$ group (G8) was fed on alcoholic extract of FN seeds-supplemented diet at a concentration of $1 \%$ and subjected to cadmium toxicity $\left(1.5 \mathrm{mg} \mathrm{Cd} \mathrm{L}^{-1}\right.$ of $\left.\mathrm{CdCl}_{2}\right)$. The $9^{\text {th }}$ group (G9) was fed on alcoholic extract of FN seeds-supplemented diet at a concentration of $3 \%$. The $10^{\text {th }}$ group (G10) was fed on alcoholic extract of FN seeds-supplemented diet at a concentration of $3 \%$ and subjected to cadmium toxicity $\left(1.5 \mathrm{mg} \mathrm{Cd} \mathrm{L}^{-1}\right.$ of $\left.\mathrm{CdCl}_{2}\right)$. The used ratios of crude and extract FN seeds were chosen based on some previous studies (Zaki et al., 2012; Awad et al., 2015). The duration of the experiment was 45 days. The design of the experiment was represented in table (1).

Table 1: The experimental design.

\begin{tabular}{llll}
\hline Groups & Description & $\begin{array}{l}\text { Fenugreek seeds (crude or } \\
\text { extract) supplemented }\end{array}$ & Cd concentration \\
\hline G1 & Control & No $(0 \%)$ & No $\left.(0 \mathrm{mg} \mathrm{Cd} \mathrm{L})^{-1}\right)$ \\
G2 & Cd & No $(0 \%)$ & Yes $\left(1.5 \mathrm{mg} \mathrm{Cd} \mathrm{L}{ }^{-1}\right)$ \\
G3 & FN Crude & Yes $(2.5 \%)$ & No $\left.(0 \mathrm{mg} \mathrm{Cd} \mathrm{L})^{-1}\right)$ \\
G4 & FN Crude Plus Cd & Yes $(2.5 \%)$ & Yes $\left(1.5 \mathrm{mg} \mathrm{Cd} \mathrm{L}^{-1}\right)$ \\
G5 & FN Crude & Yes $(5 \%)$ & No $\left(0 \mathrm{mg} \mathrm{Cd} \mathrm{L}^{-1}\right)$ \\
G6 & FN Crude Plus Cd & Yes $(5 \%)$ & Yes $\left(1.5 \mathrm{mg} \mathrm{Cd} \mathrm{L}^{-1}\right)$ \\
G7 & FN Extract & Yes $(1 \%)$ & No $\left(0 \mathrm{mg} \mathrm{Cd} \mathrm{L}^{-1}\right)$ \\
G8 & FN Extract Plus Cd & Yes $(1 \%)$ & Yes $\left(1.5 \mathrm{mg} \mathrm{Cd} \mathrm{L}^{-1}\right)$ \\
G9 & FN Extract & Yes $(3 \%)$ & No $\left(0 \mathrm{mg} \mathrm{Cd} \mathrm{L}^{-1}\right)$ \\
G10 & FN Extract Plus Cd & Yes $(3 \%)$ & Yes $\left(1.5 \mathrm{mg} \mathrm{Cd} \mathrm{L}^{-1}\right)$ \\
\hline
\end{tabular}

$\mathrm{FN}=$ Fenugreek seeds.

Fish of each aquarium were fed the tested diets twice daily at $2 \%$ of fish body weight for 45 days. A half of aquarium's water was siphoned off, twice a week, with fish feces and other waste materials and replaced with an equal volume of water maintaining the same Cd concentration.

\section{Parameters of water quality}

During the experimental period, the water quality parameters were as follows: temperature $\left(27.17 \pm 0.19^{\circ} \mathrm{C}\right)$, dissolved oxygen $\left(7.66 \pm 0.26 \mathrm{mg} \mathrm{L}^{-1}\right), \mathrm{pH}(7.45 \pm 0.08)$, electrical conductivity $\left(751.79 \mu \mathrm{mhos} \mathrm{cm}^{-1}\right)$, total dissolved solids $(488.67 \pm 49.64 \mathrm{mg}$ $\left.\mathrm{L}^{-1}\right)$, alkalinity $\left(116.83 \pm 7.05 \mathrm{mg} \mathrm{L}^{-1}\right.$ as $\left.\mathrm{CaCO}_{3}\right)$, hardness $\left(134.00 \pm 11.31 \mathrm{mg} \mathrm{L}^{-1}\right.$ as $\left.\mathrm{CaCO}_{3}\right)$, and unionized ammonia $\left(0.56 \pm 0.20 \mathrm{mg} \mathrm{L}^{-1}\right)$ with no free chlorine. The water temperature and dissolved oxygen concentrations were measured using SensION6 HACH, HACH Co., USA, whereas pH values were measured using IQ140 pH/Temp meter, IQ Scientific Instruments Inc., USA. Alkalinity, hardness, total dissolved solids, unionized ammonia, and chlorine concentrations were determined according to the standard analytical procedures of APHA (2012). Electrical conductivity (EC) values were calculated from total dissolved solids (TDS) concentrations by using the following equitation: $\mathrm{EC}=\mathrm{TDS} / 0.65$ (Rusydi, 2018).

\section{Blood samples}

At the end of the experiment (after 45 days), 20 fish from each group (10 fish/ replicate) were randomly selected and anesthetized with $0.4 \mathrm{ml} \mathrm{L}^{-1}$ of Eugenol (FA100, Tanabe Seiyaku Co. Ltd, Japan). Blood samples were collected from the caudal vein of fish by a 3-ml sterile syringe and allowed to clot at room temperature in clean, dry centrifuge tubes; centrifuged for $15 \mathrm{~min}$. at $3000 \mathrm{x}$ g to collect the serum, then stored at $-80{ }^{\circ} \mathrm{C}$ until biochemical analysis. Then fish were killed by overdose of Eugenol, dissected and samples from different tissues were collected for $\mathrm{Cd}$ residues, oxidative stress, CYP, MT and histopathological analysis. 


\section{Biochemical assays}

Serum total protein and albumin concentrations were estimated according to Cannon et al. (1974) and Tietz et al. (1990), respectively; and then serum globulin concentration was calculated by subtracting albumin from protein concentrations. Serum alanine aminotransferase (ALT) and aspartate aminotransferase (AST), uric acid, cholesterol and glucose concentrations were determined colorimetrically (JASCO V-730 spectrophotometer, Tokyo, Japan) according to Reitman and Frankel (1957), Tietz et al. (1990), Ellefson and Caraway (1976) and Caraway and Watts (1987), respectively.

\section{Determination of cadmium residues}

$\mathrm{Cd}$ concentrations, in fish tissues (liver, gills and muscle), were measured, after conc. $\mathrm{HNO}_{3}$ digestion and extraction of five pooled samples according to Chernoff (1975), using an atomic absorption spectrometry (Perkin-Elmer 3110, USA) with graphite atomizer (HGA-600).

\section{Determination of oxidative stress biomarkers and cytochrome (CYP P450 1A1)}

Liver samples were dissected and quickly dropped into liquid nitrogen, then transferred to $-80{ }^{\circ} \mathrm{C}$ until analyzed. Approximately $0.5 \mathrm{~g}$ of each liver sample was homogenized by a high speed glass-Teflon homogenizer in KCl-HEPES buffer; $0.15 \mathrm{M} \mathrm{KCl}, 0.02 \mathrm{M}$ HEPES, $\mathrm{pH} 7.5$. The homogenate was centrifuged at $9000 \mathrm{x} \mathrm{g}$ for $30 \mathrm{~min}$ at $4^{\circ} \mathrm{C}$. The supernatant was collected and stored at $-80{ }^{\circ} \mathrm{C}$ till antioxidant and CYP assays (Parente et al., 2004). Hepatic protein content was determined by the dye binding assay method (Bradford, 1976), using bovine serum albumin (Bio Basic Canada Inc.) as a standard protein. Catalase (CAT), Glutathione-S-transferase (GST), Superoxide dismutase activity (SOD) and Peroxidase (POD) activities were determined in fish liver using Agilent Cary $60 \mathrm{UV}-\mathrm{Vis}$ spectrophotometer (USA), according to Aebi (1984), Habig et al. (1974), McCord and Fridovich (1969), and Smith (1968), respectively. Cytochrome CYP450 1A1 protein level was determined by a semi-quantitative Enzyme Linked Immuno-Sorbent Assay (ELISA) as developed by Goksøyr (1991) and the optical density values were obtained by the ELISA reader (Gen 5 BioTek, ELx800, USA) at $492 \mathrm{~nm}$.

\section{Metallothionein gene expression}

Total RNA was extracted from fish liver and head kidneys using GeneJET RNA Purification Kit (Fermantas, UK) according to the manufacturer's protocol. RNA concentration and quality were assessed spectrophotometrically. RNA was reverse transcribed with Revert Aid First Strand cDNA Synthesis Kit ${ }^{\mathrm{TM}}$ (Fermentas life science Co.) using random hexamers. Reaction was performed using Bio-Rad thermo-cycler machine, USA. cDNA was PCR amplified using corresponding primers for metallothionein gene $(M T)$ and 18S rRNA was used as a reference gene. Primers were designed through NCBI web site (Table 2) and purchased from Invitrogen Corporation (Van Allen Way, Carlsbad, Canada). The relative expression level of a specific gene in the immunized fish was compared to that of non-immunized fish (Pfaffl, 2001). Statistical analyses for the mRNA transcription levels were performed with the aid of the SPSS.16 statistical package (SPSS Inc., Microsoft Co., Redmond, USA).

Table 2: Sequences of the 5' and 3' synthetic MT primer used in PCR.

\begin{tabular}{|c|c|c|}
\hline Accession number & Primers (sense and antisense $5^{\prime} \rightarrow 3^{\prime}$ & $\begin{array}{l}\text { Annealing } \\
\text { Temp. }\end{array}$ \\
\hline$M T$ & Sense: 5'- AGAGACAAGAGCAACGCCAG-3' & \\
\hline XM_003447045.4 & Antisense: 5'- ATGCTGCAGACTCCTCACTG & $58^{\circ} \mathrm{C}$ \\
\hline 18 sRNA & Sense: 5'- GGACACGGAAAGGATTGACAG3' & \\
\hline JF698683.1 & Antisense:5'- GTTCGTTATCGGAATTAACCAGAC3' & $58^{\circ} \mathrm{C}$ \\
\hline
\end{tabular}




\section{Histopathological examination}

Small portions of different tissues (gills, liver and muscles) from each treatment were fixed in $10 \%$ formalin, then dehydrated in ascending grades of alcohol and cleared in xylene. The fixed tissues were embedded in paraffin wax, sectioned at 5 $\mu \mathrm{m}$, and subsequently stained with hematoxylin and eosin (H \& E), and examined and photographed by light microscopy (Olympus CX41, Japan) fitted with camera (Olympus Camera Model E-620, Japan).

\section{Statistical analysis}

The obtained data were subjected to one-way ANOVA test. Significant differences in mean values between the experimental groups were tested using Duncan test (Duncan, 1955). All statistical analyses were performed using a computer program of SPSS Inc. (version 17.0 for Windows) at the $P<0.05$ level of significance.

\section{Ethical statement}

All experiments were conducted in accordance to the Egyptian laws and with the principles and procedures guidelines approved by the Review Committee for the use of Human or Animal Subjects, National Research Centre (NRC), Dokki, Giza, Egypt.

\section{RESULTS}

\section{Biochemical parameters}

The results of the investigated biochemical parameters revealed that Cd-treated group $(\mathrm{G} 2)$ showed significant increase $(P<0.05)$ in serum total protein, albumin, globulin, ALT, glucose and cholesterol, whereas AST and uric acid values showed significant $(P<0.05)$ decrease in relation to the control (G1) (Table 3). Dietary supplementation with FN-only for 45 days caused significant increase $(P<0.05)$ in serum protein and globulin in all groups that not subjected to Cd (G3, G5, G7 and G9) compared with G1. The cholesterol level was also increased in all FN-only groups except of G9 that received 3\% FN extract. On the other hand, there was a significant decrease $(P<0.05)$ in serum glucose in all groups that not subjected to Cd compared with G1, while, only FN extract $1 \%$ and $3 \%$ fed groups showed the more significant decrease in serum ALT, AST and uric acid values than crude FN groups. Feeding on FN in Cd-exposed groups (G4, G6, G8 and G10) showed more increase in protein levels compared with both G1 and G2. Interestingly, total globulins, showed the same pattern of protein levels in serum of these groups. The fish feeding on $1 \%$ and $3 \% \mathrm{FN}$ extract caused significant decreases $(P<0.05)$ in serum ALT and uric acid in $\mathrm{Cd}$ exposed groups compared with G2. While serum AST showed its lowest value in only G8 that feeding on 1\% FN extract compared with G2 (91.5 and $102.3 \mathrm{U} / \mathrm{l}$, respectively). Also the lowest serum uric acid value was recorded in G8 group (32.3 $\mathrm{mg} / \mathrm{l})$ compared with $\mathrm{G} 2(43.4 \mathrm{mg} / \mathrm{l})$. Unfortunately, FN caused more significant $(P<0.05)$ elevation in glucose and cholesterol levels in Cd-exposed groups than the Cd-only values (G2). 
Table 3: Levels of serum biochemical parameters, and oxidative stress biomarkers of Nile tilapia (O. niloticus) experimentally exposed to 1.5 mg Cd $\mathrm{L}^{-1}$ and feeding on fenugreek (FN) seeds crude or extract-supplemented diets for 45 days.

\begin{tabular}{|c|c|c|c|c|c|c|c|c|c|c|c|c|}
\hline & G1 & G2 & G3 & G4 & G5 & G6 & G7 & G8 & G9 & G10 & $F$-value & $P$-value \\
\hline \multicolumn{13}{|l|}{ Serum biochemical parameters } \\
\hline Protein $(\mathrm{mg} / \mathrm{ml})$ & $35.0 \pm 0.3^{\mathrm{a}}$ & $52.6 \pm 0.5^{\mathrm{c}}$ & $71.7 \pm 0.5^{\mathrm{g}}$ & $78.4 \pm 0.4^{\mathrm{i}}$ & $56.5 \pm 0.7^{\mathrm{d}}$ & $76.7 \pm 0.3^{\mathrm{h}}$ & $39.4 \pm 0.6^{\mathrm{b}}$ & $61.2 \pm 0.4^{\mathrm{f}}$ & $52.7 \pm 0.0^{\mathrm{c}}$ & $58.7 \pm 0.5^{\mathrm{e}}$ & 1009.3 & $0.000 * *$ \\
\hline Albumin $(\mathrm{mg} / \mathrm{ml})$ & $4.6 \pm 0.2^{c}$ & $9.7 \pm 0.1^{\mathrm{e}}$ & $3.8 \pm 0.1^{\mathrm{b}}$ & $2.2 \pm 0.1^{\mathrm{a}}$ & $8.2 \pm 0.3^{\mathrm{d}}$ & $14.7 \pm 0.5^{\mathrm{g}}$ & $4.2 \pm 0.3^{\mathrm{bc}}$ & $16.3 \pm 0.2^{\mathrm{h}}$ & $14.7 \pm 0.2^{\mathrm{g}}$ & $11.4 \pm 0.2^{\mathrm{f}}$ & 502.7 & $0.000 * *$ \\
\hline Globulin $(\mathrm{mg} / \mathrm{ml})$ & $30.5 \pm 0.2^{\mathrm{a}}$ & $42.9 \pm 0.2^{\mathrm{d}}$ & $67.9 \pm 0.4^{\mathrm{i}}$ & $76.1 \pm 0.5^{j}$ & $48.3 \pm 0.2^{\mathrm{g}}$ & $61.9 \pm 0.2^{\mathrm{h}}$ & $35.2 \pm 0.1^{\mathrm{b}}$ & $44.9 \pm 0.1^{\mathrm{e}}$ & $38.0 \pm 0.2^{\mathrm{c}}$ & $47.3 \pm 0.5^{\mathrm{f}}$ & 2348.3 & $0.000 * *$ \\
\hline $\operatorname{ALT}($ Unit/L) & $37.1 \pm 0.2^{\mathrm{ef}}$ & $38.2 \pm 0.6^{\mathrm{g}}$ & $38.0 \pm 0.4^{\mathrm{fg}}$ & $39.4 \pm 0.6^{\mathrm{g}}$ & $35.3 \pm 0.2^{\mathrm{cd}}$ & $36.0 \pm 0.5^{\mathrm{de}}$ & $30.2 \pm 0.5^{\mathrm{a}}$ & $34.5 \pm 0.5^{\mathrm{c}}$ & $32.5 \pm 0.5^{\mathrm{b}}$ & $35.9 \pm 0.5^{\text {cde }}$ & 36.5 & $0.000 * *$ \\
\hline AST (Unit/L) & $119.7 \pm 0.2^{\mathrm{e}}$ & $102.3 \pm 0.5^{\mathrm{c}}$ & $111.4 \pm 0.6^{\mathrm{d}}$ & $139.6 \pm 0.3^{\mathrm{h}}$ & $123.0 \pm 0.7^{\mathrm{g}}$ & $121.3 \pm 0.2^{\mathrm{f}}$ & $103.1 \pm 0.6^{\mathrm{c}}$ & $91.5 \pm 0.3^{\mathrm{a}}$ & $98.1 \pm 0.6^{\mathrm{b}}$ & $110.6 \pm 0.4^{\mathrm{d}}$ & 927.0 & $0.000 * *$ \\
\hline Glucose $(\mathrm{mg} / \mathrm{L})$ & $302.9 \pm 0.5^{\mathrm{e}}$ & $354.3 \pm 0.2^{\mathrm{f}}$ & $151.4 \pm 0.5^{\mathrm{a}}$ & $502.9 \pm 0.5^{\mathrm{i}}$ & $262.9 \pm 0.6^{\mathrm{c}}$ & $394.3 \pm 0.2^{\mathrm{h}}$ & $222.9 \pm 0.6^{\mathrm{b}}$ & $622.9 \pm 0.5^{\mathrm{j}}$ & $294.3 \pm 0.4^{\mathrm{d}}$ & $377.1 \pm 0.6^{\mathrm{g}}$ & 81477.0 & $0.000 * *$ \\
\hline Cholesterol (mg/L) & $70.2 \pm 0.6^{\mathrm{b}}$ & $91.2 \pm 0.5^{\mathrm{d}}$ & $280.7 \pm 0.5^{\mathrm{f}}$ & $228.1 \pm 0.3^{\mathrm{e}}$ & $435.1 \pm 0.2^{\mathrm{h}}$ & $705.3 \pm 0.4^{j}$ & $84.2 \pm 0.3^{\mathrm{c}}$ & $603.5 \pm 0.1^{\mathrm{i}}$ & $42.1 \pm 0.5^{\mathrm{a}}$ & $347.4 \pm 0.2^{\mathrm{g}}$ & 344709.2 & $0.000 * *$ \\
\hline Uric acid (mg/L) & $44.3 \pm 0.6^{\mathrm{e}}$ & $43.4 \pm 0.3^{\mathrm{d}}$ & $45.2 \pm 0.5^{\mathrm{e}}$ & $50.8 \pm 0.4^{\mathrm{h}}$ & $47.1 \pm 0.6^{\mathrm{f}}$ & $48.9 \pm 0.6^{\mathrm{g}}$ & $36.0 \pm 0.2^{\mathrm{b}}$ & $32.3 \pm 0.6^{\mathrm{a}}$ & $41.5 \pm 0.6^{\mathrm{c}}$ & $36.9 \pm 0.5^{\mathrm{b}}$ & 132.4 & $0.000 * *$ \\
\hline \multicolumn{13}{|l|}{ Oxidative stress biomarkers } \\
\hline Hepatic protein $(\mathrm{mg} / \mathrm{ml})$ & $6.6 \pm 0.2^{\mathrm{a}}$ & $9.8 \pm 0.6^{\text {bcde }}$ & $9.6 \pm 0.5^{\mathrm{bcd}}$ & $11.2 \pm 0.4^{\mathrm{e}}$ & $9.1 \pm 0.5^{\mathrm{bc}}$ & $9.8 \pm 0.2^{\text {bcde }}$ & $9.1 \pm 0.5^{\mathrm{bc}}$ & $10.7 \pm 0.5^{\mathrm{de}}$ & $8.9 \pm 0.3^{b}$ & $10.5 \pm 0.5^{\text {cde }}$ & 8.1 & $0.000 * *$ \\
\hline CAT (Unit/ml) & $153.3 \pm 0.2^{f}$ & $197.4 \pm 0.4^{\mathrm{i}}$ & $193.1 \pm 0.3^{\mathrm{h}}$ & $92.6 \pm 0.6^{\mathrm{c}}$ & $160.2 \pm 0.2^{\mathrm{g}}$ & $141.4 \pm 0.6^{\mathrm{e}}$ & $139.2 \pm 0.2^{\mathrm{d}}$ & $75.8 \pm 0.6^{\mathrm{a}}$ & $200.6 \pm 0.6^{j}$ & $79.5 \pm 0.5^{\mathrm{b}}$ & 11705.0 & $0.000 * *$ \\
\hline SOD (Unit/ml) & $6.5 \pm 0.6^{\mathrm{d}}$ & $7.3 \pm 0.3^{\mathrm{e}}$ & $4.5 \pm 0.3^{b}$ & $5.0 \pm 0.3^{\mathrm{bc}}$ & $6.7 \pm 0.6^{\mathrm{d}}$ & $2.5 \pm 0.4^{\mathrm{a}}$ & $6.0 \pm 0.4^{\text {cd }}$ & $4.5 \pm 0.5^{\mathrm{b}}$ & $8.6 \pm 0.5^{\mathrm{f}}$ & $4.7 \pm 0.5^{\mathrm{bc}}$ & 15.6 & $0.000 * *$ \\
\hline GST $(\mu$ mole $/ \mathrm{min} / \mathrm{mg}$ protein $)$ & $0.03 \pm 0.0^{\mathrm{a}}$ & $0.6 \pm 0.1^{\mathrm{d}}$ & $0.1 \pm 0.0^{\mathrm{a}}$ & $0.4 \pm 0.1^{\mathrm{b}}$ & $0.6 \pm 0.0^{\mathrm{cd}}$ & $0.7 \pm 0.1^{\mathrm{d}}$ & $0.8 \pm 0.0^{\mathrm{d}}$ & $0.6 \pm 0.1^{\mathrm{bcd}}$ & $0.4 \pm 0.0^{\mathrm{b}}$ & $0.4 \pm 0.0^{\mathrm{bc}}$ & 13.4 & $0.000 * *$ \\
\hline POD (Unit/ml) & $0.3 \pm 0.0^{\mathrm{a}}$ & $0.3 \pm 0.0^{\mathrm{ab}}$ & $0.4 \pm 0.1^{\mathrm{bc}}$ & $0.4 \pm 0.0^{\mathrm{ab}}$ & $0.3 \pm 0.1^{\mathrm{b}}$ & $0.4 \pm 0.1^{\mathrm{ab}}$ & $0.6 \pm 0.0^{\mathrm{d}}$ & $0.3 \pm 0.0^{\mathrm{ab}}$ & $0.3 \pm 0.1^{\mathrm{ab}}$ & $0.5 \pm 0.0^{\mathrm{cd}}$ & 7.2 & $0.000 * *$ \\
\hline CYP P450 1A1 (OD at $492 \mathrm{~nm}$ ) & $0.2 \pm 0.0^{\mathrm{a}}$ & $0.18 \pm 0.0^{\mathrm{a}}$ & $0.6 \pm 0.0^{c}$ & $0.6 \pm 0.0^{\mathrm{c}}$ & $0.6 \pm 0.0^{\mathrm{c}}$ & $0.4 \pm 0.1^{\mathrm{b}}$ & $0.6 \pm 0.0^{c}$ & $0.5 \pm 0.0^{\mathrm{c}}$ & $0.4 \pm 0.0^{\mathrm{b}}$ & $0.5 \pm 0.0^{\mathrm{c}}$ & 30.9 & $0.000 * *$ \\
\hline
\end{tabular}

$\mathrm{FN}+\mathrm{Cd} \cdot \mathrm{G} 9=3 \%$ Extract $\mathrm{FN} \cdot \mathrm{G} 10=3 \%$ Extract $\mathrm{FN}+\mathrm{Cd}$

Data are expressed as mean $\pm \mathrm{SE}(\mathrm{n}=10) . \mathrm{SE}=$ standard error.

Means with the same letter within the same raw are not significantly different $(P>0.05)$.

$F$-value $=$ ANOVA's $F$-test. $* *$ Highly significant $(P<0.001)$ 


\section{Antioxidant biomarkers and Cytochrome P450 1A1 (CYP1A1)}

A highly significant $(P<0.001)$ differences in hepatic protein, CAT, SOD, GST, and POD activities were observed within the different treatment groups (Table 3 ). The Cd treated group $(\mathrm{G} 2)$ showed significant increase $(P<0.05)$ in hepatic protein, CAT, SOD, and GST values by 1.48, 1.3, 1.1 and 20 folds, respectively, compared with G1. On the other hand, Cd exposure didn't significantly affect POD and CYP values compared with G1. Dietary supplementation with FN-only for 45 days caused increase in hepatic protein content, CAT, GST and CYP over their comparable control values (G1). The highest values of CAT and SOD activities were recorded in fish fed $3 \%$ FN extract group (G9), and highest GST and POD activities were recorded in 1\% FN extract group (G7). Fortunately, feeding on FN with $\mathrm{Cd}$ exposure caused significant decreases $(P<0.05)$ in hepatic CAT and SOD activities compared with the Cd-only group (G2). The lowest CAT value was recorded in fish fed $1 \%$ FN extract group (G8) compared with G2 (75.8 and $197.4 \mathrm{U} / \mathrm{ml}$, respectively). Also, the lowest SOD values were recorded in 5\% FN crude group followed by $1 \%$ FN extract group compared with G2.

\section{Metallothionein (MT-gene expression)}

The results of MT-gene expression was presented in Fig. 1. There was a significant up-regulation $(P<0.05)$ in $M T$-gene expression in Cd-only group compared to $\mathrm{Cd}$ non-exposed groups (Fig. 1A \& B). On the other hand, $M T$-gene expression in FN only groups; that not exposed to Cd toxicity showed insignificant $(P>0.05)$ changes (Fig. 1A). While, feeding on $\mathrm{FN}$ for 45 days in Cd-exposed groups caused significant $(P<0.05)$ up-regulation in $M T$-gene expression, with the highest value of expression, as fold change, reported with $3 \%$ FN extract followed by $1 \%$ FN extract, $5 \% \mathrm{FN}$ crude and finally $2.5 \% \mathrm{FN}$ crude (Figure 1B).

\section{Cadmium residues}

The Cd accumulation in the investigated fish organs was in the following order: liver>gills $>$ muscles and these accumulations increased 9.05, 4.77, and 1.35-fold, respectively, in G2 compared with G1 (Table 4). Cd residues in fish liver were only reduced in G8 group. And Cd residues in fish gills were reduced in G6, G8 and G10. While $\mathrm{Cd}$ residues in fish muscles showed their lower values in G6 and G8. So feeding on $1 \%$ FN extract with Cd exposure (G8) was the only group that showed significant reduction in $\mathrm{Cd}$ residues in fish liver, gills and muscles as compared with G2.

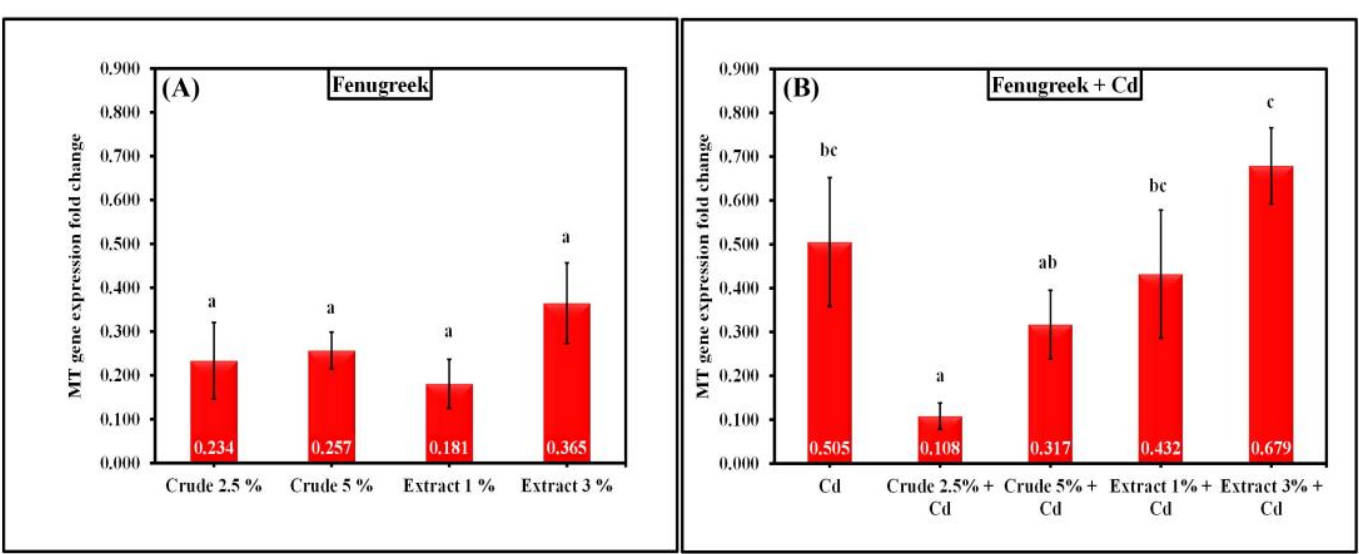

Fig. 1: The fold change of metallothionein $(M T)$ gene expression in Nile tilapia, O. niloticus: (A) fed


Bars assigned by different letters are significantly differed at $P<0.05$. 
Table 4: Cadmium residues ( $\mathrm{mg} \mathrm{kg}^{-1}$ wet weight) in liver, gills and muscles of Nile tilapia, O. niloticus, experimentally exposed to $1.5 \mathrm{mg} \mathrm{Cd} \mathrm{L}^{-1}$ and feeding on fenugreek (FN) seeds crude or extractsupplemented diet for 45 days.

\begin{tabular}{|c|c|c|c|c|c|c|c|c|}
\hline & G1 & G2 & G4 & G6 & G8 & G10 & $F$-value & $P$-value \\
\hline Liver & $4.8 \pm 0.1^{\mathrm{a}}$ & $43.7 \pm 0.3^{\mathrm{c}}$ & $45.0 \pm 0.7^{\mathrm{c}}$ & $50.3 \pm 0.4^{\mathrm{d}}$ & $20.1 \pm 0.5^{b}$ & $59.0 \pm 0.6^{\mathrm{e}}$ & 1758.6 & $0.000^{* *}$ \\
\hline Gills & $1.5 \pm 0.1^{\mathrm{a}}$ & $6.9 \pm 0.6^{c}$ & $12.1 \pm 0.6^{\mathrm{d}}$ & $5.4 \pm 0.4^{\mathrm{b}}$ & $4.5 \pm 0.7^{\mathrm{b}}$ & $5.3 \pm 0.2^{\mathrm{b}}$ & 55.8 & $0.000^{* *}$ \\
\hline Muscles & $0.3 \pm 0.0^{\mathrm{a}}$ & $0.4 \pm 0.1^{\mathrm{b}}$ & $0.8 \pm 0.1^{\mathrm{d}}$ & $0.3 \pm 0.0^{\mathrm{a}}$ & $0.3 \pm 0.0^{\mathrm{a}}$ & $0.6 \pm 0.1^{\mathrm{c}}$ & 8.2 & $0.001 * *$ \\
\hline
\end{tabular}

\section{Histopathological alterations}

The histopathological examination of the control group revealed normal structure of musculature, gills, and liver (Fig. 2A-C). In groups exposed to FN extract, the musculature showed edema and Zenker's necrosis (Fig. 2D). Gills exhibited congestion in the lamellar and branchial blood vessels, and severe hyperplasia in the secondary lamellae, associated with degenerative and necrotic changes in the respiratory epithelial cells lining the secondary lamellae (Fig. 2E). Liver showed severe vacuolar degeneration and necrotic changes in the hepatocytes (Fig. 2F). The histopathological picture became very severe, in fish exposed to FN crude, where the musculature showed high degree of degenerative changes, edema and Zenkers necrosis (Fig. 2G). Gills appeared congested associated with telangiectases (lamellar capillary aneurisms) at the tips of the secondary lamellae, and moderate degree of hyperplasia in the epithelial lining of the secondary lamellae (Fig. 2H). Liver showed severe congestion in the hepatic blood vessels, associated with severe vacuolar degeneration and necrotic changes in the hepatocytes (Fig. 2I). In fish exposed to $1.5 \mathrm{mg} \mathrm{L}^{-1}$ of $\mathrm{CdCl}_{2}$, the musculature showed edema, degenerative and necrotic changes (Fig. 3A). Gills showed telangiectases at the tips of the secondary lamellae, severe hyperplasia, degenerative and necrotic changes in the respiratory epithelial lining (primary and secondary lamellae) and congestion were also observed (Figs. 3B1 \& 3B2). Liver showed diffuse cloudy swelling, necrotic changes, vacuolar degeneration with infiltration of mononuclear cells in-between the hepatocytes, with activation of melano-macrophage centers (Fig. 3C). The musculature showed mild edema and Zenker's necrosis (Fig. 3D) in the group exposed to $1.5 \mathrm{mg} \mathrm{L}^{-1}$ of $\mathrm{CdCl}_{2}$ plus FN extract. Gills showed clubbing at the ends of the primary gill lamellae, moderate hyperplasia at the base of secondary gill lamellae associated with degenerative and necrotic changes in the respiratory epithelial cells lining the secondary lamellae, and congestion (Fig. 3E). Liver showed moderate diffuse vacuolar degeneration and necrotic changes in the hepatocytes with infiltration of mononuclear cells in-between the hepatocytes (Fig. 3F). In the fish treated with $1.5 \mathrm{mg} \mathrm{L}^{-1}$ of $\mathrm{CdCl}_{2}$ plus $\mathrm{FN}$ crude, the musculature revealed edema, degenerative changes and Zenker's necrosis (Fig. 3G). Gills have congestion in the lamellar and branchial blood vessels, clubbing at the ends of the primary gill lamellae, severe degree of hyperplasia and separation of the epithelial lining of the secondary gill lamellae (Fig. 3H). Liver showed severe congestion in the hepatic blood vessels, severe vacuolar degeneration and necrotic changes in both hepatocytes and pancreatic tissues associated with infiltration of mononuclear cells in-between the hepatocytes and infiltration of melano-macrophage cells nearby the necrotic areas (Fig. 3I). Generally, it was found that there was a reduction in the size of inflammatory cell infiltration and hyperplasia areas and a reduction in the number of necrotic cells in fish exposed to $1.5 \mathrm{mg} \mathrm{L}^{-1}$ of $\mathrm{CdCl}_{2}$ plus $\mathrm{FN}$ extract compared to $\mathrm{FN}$ crude. 


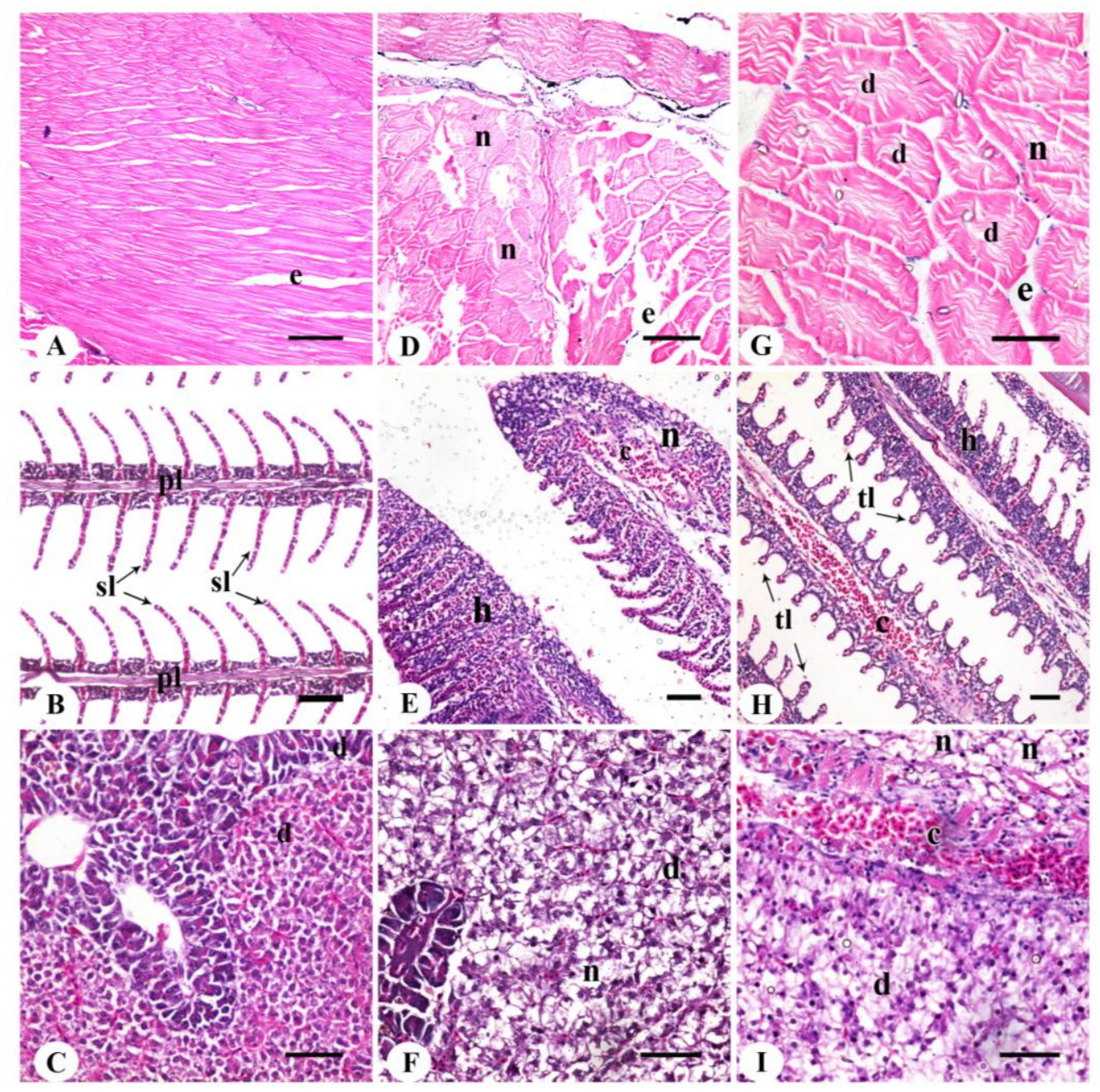

Fig. 2: (A-C) O. niloticus control fish group: (A) Musculature showing normal structure with slight edema between the muscular fibers. (B) Gills showing normal lamellar structure (primary and secondary lamellae). (C) Liver (Hepatopancreas) showing normal hepatic and pancreatic structures with mild degenerative changes in the pancreatic acinar cells also in some hepatocytes. (D-F) O. niloticus fish treated with FN seeds extract: (D) Musculature showing edema and Zenker's necrosis. (E) Gills showing congestion in the lamellar and branchial blood vessels, severe hyperplasia in the secondary lamellae, associated with degenerative and necrotic changes in the respiratory epithelial cells lining the secondary lamellae. (F) Liver showing severe vacuolar degeneration and necrotic changes in the hepatocytes. (G-I) O. niloticus fish treated with crude FN seeds: (G) Musculature showing high degree of degenerative changes, edema and Zenkers necrosis. $(\mathrm{H})$ Gills showing congestion in the lamellar and branchial blood vessels, telaniegctasis and moderate degree of hyperplasia in the epithelial lining of the secondary lamellae. (I) Liver showing severe congestion in the hepatic blood vessels, severe vacuolar degeneration and necrotic changes in the hepatocytes. $\mathrm{e}=$ edema, $\mathrm{n}=$ necrosis, $\mathrm{h}=$ hyperplasia, $\mathrm{d}=$ degeneration, $\mathrm{c}=$ congestion, $\mathrm{pl}=$ primary lamellae, $\mathrm{sl}=$ secondary lamellae, $\mathrm{tl}$ $=$ telaniegctasis. $(\mathrm{H} \& \mathrm{E}, \mathrm{Bar}=50 \mu \mathrm{m})$. 




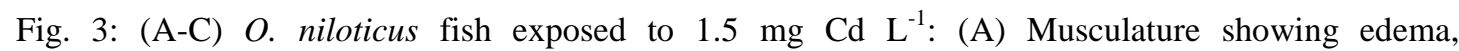
degenerative and necrotic changes. (B1) Gills showing telangiectasis. (B2) Gills showing telangiectasis, severe hyperplasia, degenerative and necrotic changes in the respiratory epithelial lining (primary and secondary lamellae) and congestion. (C) Liver showing diffuse cloudy swelling, necrotic changes, vacuolar degeneration, and infiltration of mononuclear cells inbetween the hepatocytes with activation of melano-macrophage centers. (D-F) O. niloticus fish exposed to $1.5 \mathrm{mg} \mathrm{Cd} \mathrm{L}^{-1}$ and fed with FN seeds extract: (D) Musculature showing edema and Zenker's necrosis. (E) Gills showing clubbing, moderate hyperplasia at the base of secondary gill lamellae, degenerative and necrotic changes in the respiratory epithelial cells lining the secondary lamellae, and congestion. (F) Liver showing moderate diffuse vacuolar degeneration and necrotic changes and infiltration of mononuclear cells in-between the hepatocytes. (G-I) $O$. niloticus fish exposed to $1.5 \mathrm{mg} \mathrm{Cd} \mathrm{L}^{-1}$ and fed with crude FN seeds: (G) Musculature showing edema, degenerative changes and Zenker's necrosis. (H) Gills showing congestion in the lamellar and branchial blood vessels, clubbing, hyperplasia and separation of the epithelial lining of the secondary gill lamellae. (I) Liver showing severe congestion, severe vacuolar degeneration and necrotic changes in both hepatocytes and pancreatic tissues, infiltration of mononuclear cells in-between the hepatocytes and infiltration of melano-macrophage cells nearby the necrotic areas. $\mathrm{e}=$ edema, $\mathrm{n}=$ necrosis, $\mathrm{h}=$ hyperplasia, $\mathrm{d}=$ degeneration, $\mathrm{c}=$ congestion, $\mathrm{m}=$ mononuclear inflammatory cells, $\mathrm{mmcs}=$ melano-macrophage cells/centers, $\mathrm{tl}$ $=$ telaniegctasis, $\mathrm{cl}=$ clubbing, $\mathrm{s}=$ separation. $(\mathrm{H} \& \mathrm{E}, \mathrm{Bar}=50 \mu \mathrm{m})$. 


\section{DISCUSSION}

Cadmium pollution is one of the most harmful heavy metal pollutants in the aquatic environments. Even at sub-lethal concentrations, Cd has a cumulative effect and causes serious physiologic disturbances in fish (Abdel-Tawwab and Wafeek, 2014; Abdel-Tawwab and Wafeek, 2017; Khalesi et al., 2017) and humans (Marengo et al., 2018). So, for Cd detoxification, a scientific tool is essential to sustain the health of the economic farmed fish. Natural products, such as plants and their extracts, have received much attention because they could increase appetite, promote growth, enhance immune ability, and have anti-pathogenic properties in fish (Abdel-Tawwab, 2016; Abdel-Tawwab et al., 2018). In recent years, one of these plants that have gained attention is FN (Mostafa et al., 2009; Mehboob et al., 2017; Roohi et al., 2017).

In the current study, the significant increase in the serum total protein (hyperproteinemia), albumin and globulin contents that were observed in G2 indicated that the total protein influential balance was broken and body health of fish, immune response and antioxidant capability were affected (Sayed and Authman, 2018). During stress conditions, fish need more energy to overcome and detoxify pollutants, so proteins in the liver degrade and the serum protein level increase (Authman et al., 2013). In line with our results, El-Serafy et al. (2013) observed a very highly significant increase in the plasma total proteins, albumin and globulin content in Nile tilapia, O. niloticus fish fed on $\mathrm{CdCl}_{2}$ contaminated diet. Consistent with the results of Mostafa et al. (2009) and Roohi et al. (2017), FN-only supplementation resulted in a significant increase in the serum protein and globulin compared with the control, because FN contains selenium that may increase production of protein in liver (AbdelTawwab et al., 2007). Concerning Cd+FN exposed groups; protein level is higher than the FN groups without $\mathrm{Cd}$ exposure that may be returned to the toxic effect of $\mathrm{Cd}$, redox reactions and antioxidant enzymes induction (Asagba et al., 2008). Concerning liver enzymes such as ALT and AST, they are considered important plasma indicators to examine the animal health (Mohiseni et al., 2016) and also used as stress indicators (Al-Asgah et al., 2015). In the present study, Cd-only exposure significantly increased ALT activity and decreased AST activity, compared with the control group. Metals can either decrease or increase activities of hepatic enzymes and can induce histopathological changes in liver, depending on the metal type, its concentration, duration of exposure, fish species and other factors (FigueiredoFernandes et al., 2007). During metal stress, to counter the energy demand, enhancement of ALT or AST activities may happen; while sometimes high metal accumulations in the tissues decrease ALT or AST activities (Öner et al., 2009). High levels of ALT or AST in blood may be because of liver cellular damage that represents a usually indicative of necrosis and disease in the animal's liver (Mohiseni et al., 2016). This was matched the histopathological changes noted in current study in liver sections of Cd-exposed fish (Fig. 3C). In accordance, Abbas et al. (2007) observed inhibition in AST activities of Nile tilapia, O. niloticus, whereas, Al-Asgah et al. (2015) mentioned significant increase in ALT activity after O. niloticus exposure to $\mathrm{Cd}$. The significant $(P<0.05)$ low values of ALT and AST in both Cdexposed and non-exposed groups, supplemented by $1 \%$ and $3 \%$ FN extract, than their comparable control, agrees with the findings of Sushma and Devasena (2010) who found reduction in hepatic enzymes (ALT and AST) in rats fed on FN which have protective effect against hepatotoxicity. On the other hand, Mostafa et al. (2009) found no significant difference in AST activity and significant increase in ALT 
activity in monosex Nile tilapia, $O$. niloticus fingerlings feeding on FN. Urea, uric acid and creatinine are valuable indices for health of the gills and kidneys (Y1lmaz et al., 2012). Plasma uric acid can be considered as a glomerular filtration rate rough index (Maita et al., 1984). In the present work, Cd-only exposure displayed a significant decreased level of uric acid compared to the control fish. Abbas et al. (2007) confirmed similar data of uric acid in O. niloticus exposed to Cd. Y1lmaz et al. (2012) found that FN as feed additive did not change uric acid levels of sea bass (Dicentrarchus labrax). The present study results proved that FN extract had an ameliorative effect against liver injury induced by $\mathrm{Cd}$ toxicity. This may be due to its antioxidant activity (Sakr et al., 2009).

Glucose level in blood have long been used as a reliable and sensitive indicator of contaminants causing stress in fish, whereas the increase in blood cholesterol concentration is used as an liver dysfunction indicator; because one of the main liver functions is lipids homeostasis (Osman et al., 2018); or damages to kidney (Roohi et al., 2017). In the current work, the significantly higher glucose value in Cd-only intoxicated fish might be because of the vulnerable stress induced by $\mathrm{Cd}$ toxicity lead to hyperglycemia. Levesque et al. (2002) concluded that trace metals modulate the carbohydrates metabolism, causing hyperglycemia by stimulating glycogenolysis in fish. Our results agreeing with the data reported by Al-Asgah et al. (2015) and Mohiseni et al. (2016) who showed blood glucose levels elevation in Nile tilapia and common carp exposed to $\mathrm{Cd}$. Moreover, the blood cholesterol level in Cd-only intoxicated fish was significantly increased (hypercholesteremia) compared to control group. As a response to pollution, the cholesterol level increased because organisms required excess energy reserves to mediate the stress effects. In addition, the failure of liver and kidney causes release of cholesterol into the fish blood (Mohiseni et al., 2016). In Cd+FN exposed groups, the continuous elevations in glucose and cholesterol levels may be returned to the Cd effect and pointed that $\mathrm{FN}$ has no effect to modulate glucose and cholesterol levels in Cd-exposed fish. In stress state, the increase in the circulating corticosteroids or catecholamines concentration results in hyperglycemia (Min and Kang, 2008). On the other hand, fish feeding on FN-only (crude and extract) and not subjected to Cd toxicity stress showed decrease in glucose level in the serum, that may be returned to the hypoglycemic effect of FN. Roohi et al. (2017) mentioned that, FN has a hypoglycaemic effect on the body because it contains galactomannan (mucilaginous fibers). In the current study, unexpected increase in cholesterol level in $O$. niloticus feeding on crude FN seeds $(2.5$ and $5 \%)$ may be explained by the possible toxic effect of high FN doses on fish. Contradicting to our results, Roohi et al. (2017) demonstrated significantly lower cholesterol levels in common carp, $C$. carpio fed supplemented diet by $1 \%$ FN seed. However the $1 \%$ and $3 \%$ FN extracts decreased the cholesterol level. Previous studies indicated that the FN seeds ethanol extract contained saponins, which have hypocholesterolemic effects, where in the digestive tract; it increases the conversion of hepatic cholesterol to bile salts, and it increases the loss of these substances complexes and neutral sterols in the feces (Srinivasan, 2006; Helal et al., 2018).

In the current study, hepatic protein, CAT, SOD, and GST activities were significantly increased in Cd-only exposed $O$. niloticus fish as compared with the control. The increase in total protein levels in the serum of Cd-only exposed fish confirmed the hepatic protein increase. Roohi et al. (2017) mentioned that, increased total protein levels in fish serum possibly reflects increased protein synthesis in liver, because of the close relationship between the rate of liver tissue protein synthesis and the serum total protein concentrations. The observed elevated CAT, SOD and GST 
levels show the possible shift towards a mechanism of detoxification under long-term $\mathrm{Cd}$ exposure. Zirong and Shijun (2007) mentioned that, in fish, Cd exposure causes harmful effects on oxidative stress responses, because it could produce ROS (directly or indirectly). Atli and Canli (2010) reported that Cd (redox-inactive metal) can cause increases in ROS production significantly, followed by oxidative stress situation, leading to DNA, proteins and lipids dysfunctions. Similarly, Abdel-Tawwab and Wafeek (2017), Mushtaq et al. (2017) and Li et al. (2018) reported increased activities of oxidative system enzymes (i.e. CAT, SOD and GST) in different fish species exposed to $\mathrm{Cd}$ and other metals, indicating that the antioxidant system response to metal stress and a possible shift toward a detoxification mechanism. Feeding on FN extract with Cd exposure showed significant decreases in CAT and SOD activities, compared to the control group. This indicates to the protective role of FN since it can modulate the toxic effect of $\mathrm{Cd}$. Also, the variations in other antioxidant enzymes may be returned to Cd toxic effect. The effect of heavy metal exposure on the activities of antioxidant enzymes had been inconclusive, showing no change (Porte et al., 2002), inhibition (Messina et al., 2014), or induction of these enzymes (Abdel-Tawwab et al., 2017). In fish groups feeding on FN-only supplemented diet, FN increased the hepatic protein content, CAT and GST activities over the control group. Present findings agree with Awad et al. (2015) who found an up-regulation in liver gene expression; CAT, SOD and GR (glutathion reductase) of Sparus aurata (L.) fed 5\% and 10\% FN-supplemented diets. Adding to that, Bahi et al. (2017) mentioned that the increase in the serum peroxidase activity of Sparus aurata (L.) feed with diets supplemented with FN seeds and probiotics may have been due solely to FN supplementation. The flavonoid and phenolic compounds contained in FN would help to increase its antioxidant ability in liver (Dixit et al., 2005; Guardiola et al., 2017). The characteristic functions of higher content of flavonoids (such as quercetin, kaempferol and apigenin) and saponins (such as yamogenin and diosgenin) in FN are to protect the oxidative damage and have immunostimulatory properties (Y1lmaz et al., 2012). Also, the phenolics antioxidant property is due to their redox properties. They act as hydrogen donors, reducing agents (free radical terminators) and singlet oxygen quenchers (Belguith-Hadriche et al., 2013).

The present study revealed that exposure to Cd-only for 45 days, inhibited CYP 450 activity compared with the control and other treatment groups. Several previous studies have reported similar inhibition of activities of CYP 450 in fish after exposure to Cd which may be due to cell damages (Hassanain et al., 2007; Chen and Chan, 2018). Because of the metals high affinity to SH (sulfhydryl)-residues, they react with cellular ligands, producing complexes with SH-containing molecules, such as the thiol group of the CYP cystein which is linked to the heme iron (Risso-de Faverney et al., 2000). The hastened heme turnover caused by metals may significantly decrease the oxidative role of the cell, including that of the protective microsomal CYP450 monooxygenase system (Hassanain et al., 2007). Many reports are harmonious with the perspective that CYP450 enzymes were depressed because of heme depletion (Xu et al., 2018). In the current work, administrating FN-supplemented diet to fish (without or with Cd exposure) showed significantly up-regulation of CYP450 activity compared to control. The significant increase in CYP450 activity in fish fed on FN may be due to its active compounds such as flavonoids compounds (Guardiola et al., 2017). Many flavonoids have been reported to be potent inducers of various CYPs (Hodek et al., 2002). For example, diosmin, and its aglycone form, diosmetin, quercetin and galangin, increased the CYP1A1 expression (Zhou et al., 2003). 
In the current work, the higher $M T$ mRNA expression found in Cd-only exposed group may be because of the affinity between $\mathrm{Cd}$ and $M T$ where $M T$ is able to bind $\mathrm{Cd}$ (Atli and Canli, 2003; Abdel-Tawwab and Wafeek, 2014). The presence of many thiol groups is the $M T$ main characteristic, those are capable to bind to divalent cations. Forming this complex prevents $\mathrm{Cd}$ from remaining as a free ion, its most toxic form (Le Croizier et al., 2018). Similarly, Abdel-Tawwab and Wafeek (2014) observed increase in $M T$ concentrations in different organs of Nile tilapia exposed to $\mathrm{Cd}$. In the present study, it was found that administration of FN enhanced the expression of $M T$ in Cd-exposed groups more than non-exposed groups. Present results show that FN has a role in stimulating $M T$ expression for binding to $\mathrm{Cd}$ and eliminating its hazardous effects. This effect may be possibly attributed to their antioxidant properties that seemed to be associated with total flavonoids; total phenolic and anthocyanin content ( $\mathrm{Li}$ et al., 2017).

The present data agreed with Al-Asgah et al. (2015) who reported that muscles of $O$. niloticus accumulated the lowest metal concentration during $\mathrm{Cd}$ exposure. In Cd-exposed fish groups feeding on FN; it was found that $\mathrm{Cd}$ levels were decreased significantly with the $1 \% \mathrm{FN}$ extract, which is the more effective dose in reducing $\mathrm{Cd}$ accumulation in tissues (especially muscle) of Cd-exposed fish groups. So, present results suggested that $1 \% \mathrm{FN}$ extract supplementation may have a role in reducing the $\mathrm{Cd}$ accumulation in fish tissues. The major pharmacologically active ingredients of $\mathrm{FN}$ are flavonoids, which appear to be responsible for reducing the $\mathrm{Cd}$ accumulation in fish tissues. The probable mechanism of flavonoids influential lowering effect on $\mathrm{Cd}$ content in tissues of Nile tilapia may be its metal chelating capacity which sequentially may lessen the tissue $\mathrm{Cd}$ load. Agreeing with this suggestion, Li et al. (2017) reported that flavonoids can alleviate Cd toxicity by means of three aspects: 1) unabsorbed flavonoids can lessen accumulated $\mathrm{Cd}$ in the body by chelating it in the intestine and increasing its excretion; 2) absorbed flavonoids in the circulation play role in toxicity reduction; 3) flavonoids metabolites also have protective effects against damage induced by $\mathrm{Cd}$. Also, phenolics in $\mathrm{FN}$ act as metal chelators (Belguith-Hadriche et al., 2013). Abdel-Tawwab (2015) also recorded a reduction of copper in fish tissues after supplementation with American ginseng.

In agree with the present work, Abbas et al. (2007) and Al-sawafi et al. (2017) observed that $\mathrm{Cd}$ exposure resulted in many histopathological alterations in fish gills, liver, and muscles. In the current work, after FN-only (crude or extract) supplementation to fish, the observed histopathological lesions may be due to the presence of saponins in FN. Francis et al. (2002) mentioned that, saponins are toxic to fish due to their harmful effect on the respiratory epithelia. Also, mild hepatitis and early liver degeneration were noted in mice at FN extract higher doses (Abdel-Barry and Al-Hakiem, 2000). Besides, in the present study, increasing CYP 450 expression may be responsible for the FN side histopathological effects in fish tissues. Yarru et al. (2009) suggested that, the over CYP gene expression produces more ROS, which impelling an oxidative stress that lead to tissues damage. In the present study, fish exposed to $\mathrm{Cd}$ and feed on $\mathrm{FN}$-supplemented diet (crude and extract) showed reduction in the damage of gills, liver and muscle histology, with FN extract gave more reduction in Cd histopathological effects than FN crude. These histopathological findings revealed that FN extract-supplemented diets (especially 1\% FN extract) can overcome the negative effects of Cd better than the FN crude-supplemented diets. This may be due to the higher content of antioxidants (i.e. phenolics and flavonoids) in FN extract. Dixit et al. (2005) reported that the extract of FN had a high flavonoid 
and phenolic content being responsible for the radical scavenging and antioxidant activities of the extract.

\section{CONCLUSION}

The present study confirmed the toxic effect of $\mathrm{Cd}$ on biochemical, antioxidant and histopathological features of Nile tilapia, O. niloticus. Also, it revealed the promising role of fenugreek extract to alleviate $\mathrm{Cd}$-induced biochemical and antioxidant changes. Feeding of fish on fenugreek extract with $\mathrm{Cd}$ exposure also reduced the histopathological changes compared with that induced by $\mathrm{Cd}$ toxicity only. Generally, it was found that FN extracts, especially $1 \%$ was more effective in alleviation most of the destructive effects of $\mathrm{Cd}$ than $\mathrm{FN}$ crudes. In addition $1 \% \mathrm{FN}$ extract reduced the $\mathrm{Cd}$ accumulated in fish muscles, which is very important issue from the public health (human consumer's health) viewpoint.

\section{ACKNOWLEDGMENTS}

The authors are grateful and do acknowledge the National Research Centre (NRC), Egypt, for financially supporting the Research Project titled "Assess the role of some medicinal plants in enhancing the productivity of Nile tilapia (Oreochromis niloticus) fish" (Research Project No.: 11020301) which the present work was a part of it.

\section{REFERENCES}

Abbas, H.H.H.; Mahmoud, H.M. and Miller, J.D. (2007). Vitamin C and cadmium toxicity in fish Oreochromis niloticus. Online J. Vet. Res., 11(1): 54-74. http://onljvetres.com/fishcadmiumabs2007.htm

Abdel-Barry, J.A. and Al-Hakiem, M.H.H. (2000). Acute intraperitoneal and oral toxicity of the leaf glycosidic extract of Trigonella foenum-graecum in mice. J. Ethnopharmacol., 70(1): 65-68. https://doi.org/10.1016/S0378-8741(99)00109-9

Abdel-Tawwab, M. (2015). The use of American Ginseng (Panax quinquefolium) in practical diets for Nile tilapia (Oreochromis niloticus): resistance to waterborne copper toxicity. Aquacult. Res., 46(4): 1001-1006. https://doi.org/10.1111/are.12237

Abdel-Tawwab, M. (2016). Feed supplementation to freshwater fish: Experimental approaches. LAP LAMBERT Academic Publishing, Berlin, Germany.

Abdel-Tawwab, M.; Adeshina, I.; Jenyo-Oni, A.; Ajani, E.K. and Emikpe, B.O. (2018). Growth, physiological, antioxidants, and immune response of African catfish, Clarias gariepinus (B.), to dietary clove basil, Ocimum gratissimum, leaf extract and its susceptibility to Listeria monocytogenes infection. Fish Shellfish Immunol., 78: 346-354. https://doi.org/10.1016/j.fsi.2018.04.057

Abdel-Tawwab, M.; El-Sayed, G.O.; Monier, M.N. and Shady, S.H. (2017). Dietary EDTA supplementation improved growth performance, biochemical variables, antioxidant response, and resistance of Nile tilapia, Oreochromis niloticus (L.) to environmental heavy metals exposure. Aquaculture, 473: 478-486. https://doi.org/10.1016/j.aquaculture.2017.03.006

Abdel-Tawwab, M.; Mousa, M.A.A. and Abbass, F.E. (2007). Growth performance and physiological response of African catfish, Clarias gariepinus (B.) fed 
organic selenium prior to the exposure to environmental copper toxicity. Aquaculture, 272(1): 335-345.

https://doi.org/10.1016/j.aquaculture.2007.09.004

Abdel-Tawwab, M. and Wafeek, M. (2014). Influence of water temperature and waterborne cadmium toxicity on growth performance and metallothioneincadmium distribution in different organs of Nile tilapia, Oreochromis niloticus (L.). J. Therm. Biol., 45: 157-162. https://doi.org/10.1016/j.jtherbio.2014.09.002

Abdel-Tawwab, M. and Wafeek, M. (2017). Fluctuations in water temperature affected waterborne cadmium toxicity: Hematology, anaerobic glucose pathway, and oxidative stress status of Nile tilapia, Oreochromis niloticus (L.). Aquaculture, 477: 106-111. https://doi.org/10.1016/j.aquaculture.2017.05.007

Aebi, H. (1984). [13] Catalase in vitro. In: "Methods in Enzymology: Oxygen Radicals in Biological Systems." Packer, L. (Ed.). Academic Press, Inc., New York: pp. 121-126. https://doi.org/10.1016/S0076-6879(84)05016-3

Al-Asgah, N.A.; Abdel-Warith, A.-W.A.; Younis, E.-S.M. and Allam, H.Y. (2015). Haematological and biochemical parameters and tissue accumulations of cadmium in Oreochromis niloticus exposed to various concentrations of cadmium chloride. Saudi J. Biol. Sci., 22(5): 543-550.

https://doi.org/10.1016/j.sjbs.2015.01.002

Al-Sawafi, A.G.A.; Wang, L. and Yan, Y. (2017). Cadmium Accumulation and Its Histological Effect on Brain and Skeletal Muscle of Zebrafish. J. Heavy Met. Toxic. Dis., 2(1): 2, 6 p. https://doi.org/10.21767/2473-6457.100017

APHA, (American Public Health Association) (2012). Standard Methods for the Examination of Water and Wastewater. APHA, AWWA \& WEF, 22 ${ }^{\text {nd }}$ ed., Washington D.C., 1496 p.

Asagba, S.O.; Eriyamremu, G.E. and Igberaese, M.E. (2008). Bioaccumulation of cadmium and its biochemical effect on selected tissues of the catfish (Clarias gariepinus). Fish Physiol. Biochem., 34(1): 61-69. https://doi.org/10.1007/s10695-007-9147-4

Atli, G. and Canli, M. (2003). Natural occurrence of metallothionein-like proteins in the liver of fish Oreochromis niloticus and effects of cadmium, lead, copper, zinc, and iron exposures on their profiles. Bull. Environ. Contam. Toxicol., 70(3): 619-627. https://doi.org/10.1007/s00128-003-0030-4

Atli, G. and Canli, M. (2010). Response of antioxidant system of freshwater fish Oreochromis niloticus to acute and chronic metal $(\mathrm{Cd}, \mathrm{Cu}, \mathrm{Cr}, \mathrm{Zn}, \mathrm{Fe})$ exposures. Ecotoxicol. Environ. Saf., 73(8): 1884-1889. https://doi.org/10.1016/j.ecoenv.2010.09.005

Authman, M.M.N.; Abbas, W.T. and Gaafar, A.Y. (2012). Metals concentrations in Nile tilapia Oreochromis niloticus (Linnaeus, 1758) from illegal fish farm in AlMinufiya Province, Egypt, and their effects on some tissues structures. Ecotoxicol. Environ. Saf., 84: 163-172. https://doi.org/10.1016/j.ecoenv.2012.07.005

Authman, M.M.N.; Ibrahim, S.A.; El-Kasheif, M.A. and Gaber, H.S. (2013). Heavy metals pollution and their effects on gills and liver of the Nile catfish Clarias gariepinus inhabiting El-Rahawy Drain, Egypt. Glob. Vet., 10(2): 103-115. https://doi.org/10.5829/idosi.gv.2013.10.2.71226

Awad, E.; Cerezuela, R. and Esteban, M.Á. (2015). Effects of fenugreek (Trigonella foenum graecum) on gilthead seabream (Sparus aurata L.) immune status and growth performance. Fish Shellfish Immunol., 45(2): 454-464. 
https://doi.org/10.1016/j.fsi.2015.04.035

Azwanida, N.N. (2015). A review on the extraction methods use in medicinal plants, principle, strength and limitation. Med. Aromat. Plants, 4:196(03): 6 p. http://dx.doi.org/10.4172/2167-0412.1000196

Bahi, A.; Guardiola, F.A.; Messina, C.; Mahdhi, A.; Cerezuela, R.; Santulli, A.; Bakhrouf, A. and Esteban, M.A. (2017). Effects of dietary administration of fenugreek seeds, alone or in combination with probiotics, on growth performance parameters, humoral immune response and gene expression of gilthead seabream (Sparus aurata L.). Fish Shellfish Immunol., 60: 50-58. https://doi.org/10.1016/i.fsi.2016.11.039

Belguith-Hadriche, O.; Bouaziz, M.; Jamoussi, K.; Simmonds, M.S.J.; El Feki, A. and Makni-Ayedi, F. (2013). Comparative study on hypocholesterolemic and antioxidant activities of various extracts of fenugreek seeds. Food Chem., 138(2): 1448-1453. https://doi.org/10.1016/j.foodchem.2012.11.003

Bobocea, A.C.; Fertig, E.T.; Pislea, M.; Seremet, T.; Katona, G.; Mocanu, M.; Doagă, I.O.; Radu, E.; Horváth, J.; Tanos, E.; Katona, L. and Katona, E. (2008). Cadmium and soft laser radiation effects on human $\mathrm{T}$ cells viability and death style choices. Rom. J. Biophys., 18(3): 179-193.

https://www.rjb.ro/articles/210/acbob.pdf

Bradford, M.M. (1976). A rapid and sensitive method for the quantitation of microgram quantities of protein utilizing the principle of protein-dye binding. Anal. Biochem., 72(1): 248-254. https://doi.org/10.1016/0003-2697(76)90527-3

Cannon, D.C.; Olitzky, I. and Inkpen, J.A. (1974). Proteins. In: "Clinical Chemistry: Principles and Techniques. 2nd ed." Henry, R.J.; Cannon, D.C. \& Winkelman, J.W. (Eds.). Harper and Row Publ., London, England, pp. 407-421

Caraway, W.T. and Watts, N.B. (1987). Carbohydrates. In: "Fundamentals of Clinical Chemistry. 3rd ed." Tietz, N.W. (Ed.). WB Saunders Co., Philadelphia, pp. $422-447$

Chang, J. (2000). Medicinal Herbs: Drugs or Dietary Supplements? Biochem. Pharmacol., 59(3): 211-219. https://doi.org/10.1016/S0006-2952(99)00243-9

Chen, Y.Y. and Chan, K.M. (2018). Transcriptional inhibition of TCDD-mediated induction of cytochrome P450 1A1 and alteration of protein expression in a zebrafish hepatic cell line following the administration of TCDD and $\mathrm{Cd}^{2+}$. Toxicol. Lett., 282: 121-135. https://doi.org/10.1016/j.toxlet.2017.10.017

Chernoff, B. (1975). A Method for Wet Digestion of Fish Tissue for Heavy Metal Analyses. Trans. Am. Fish. Soc., 104(4): 803-804. https://doi.org/10.1577/1548-8659(1975)104<803:AMFWDO>2.0.CO;2

Dixit, P.; Ghaskadbi, S.; Mohan, H. and Devasagayam, T.P.A. (2005). Antioxidant properties of germinated fenugreek seeds. Phytother. Res., 19(11): 977-983. https://doi.org/10.1002/ptr.1769

Duncan, D.B. (1955). Multiple Range and Multiple $F$ Tests. Biometrics, 11(1): 1-42. https://doi.org/10.2307/3001478

El-Kady, A.A. and Abdel-Wahhab, M.A. (2018). Occurrence of trace metals in foodstuffs and their health impact. Trends Food Sci. Technol., 75: 36-45. https://doi.org/10.1016/j.tifs.2018.03.001

El-Sayed, A.-F.M. (2006). Tilapia culture. Oxfordshire, United Kingdom: CABI Publishing, CABI International Willingford, $276 \mathrm{p}$.

El-Serafy, S.S.; Zowail, M.E.; Abdel-Hameid, N.-A.H.; Awwad, M.H. and Omar, E.H. (2013). Effect of dietborne metals on body indices of Nile tilapia 
(Oreochromis niloticus) with emphasis on protein pattern. Egypt. J. Exp. Biol. (Zool.), 9(1): 15-24. http://www.egyseb.net/ejebz/?mno=187376

Ellefson, R.D. and Caraway, W.T. (1976). Lipids and Lipoproteins. In: "Fundamentals of Clinical Chemistry." Tietz, N.W. (Ed.). W.B. Saunders Co., Philadelphia: pp. 474-542.

FAO (2014). The State of World Fisheries and Aquaculture 2014: Opportunities and Challenges. Food and Agriculture Organization of the United Nations (FAO), Rome, 223 p. www.fao.org/3/a-i3720e.pdf

Figueiredo-Fernandes, A.; Ferreira-Cardoso, J.V.; Garcia-Santos, S.; Monteiro, S.M.; Carrola, J.; Matos, P. and Fontaínhas-Fernandes, A. (2007). Histopathological changes in liver and gill epithelium of Nile tilapia, Oreochromis niloticus, exposed to waterborne copper. Pesqui. Vet. Brasil., 27(3): 103-109. http://dx.doi.org/10.1590/S0100-736X2007000300004

Francis, G.; Kerem, Z.; Makkar, H.P.S. and Becker, K. (2002). The biological action of saponins in animal systems: a review. Br. J. Nutr., 88(6): 587-605. https://doi.org/10.1079/BJN2002725

Garcia-Santos, S.; Fontaínhas-Fernandes, A. and Wilson, J.M. (2006). Cadmium tolerance in the Nile tilapia (Oreochromis niloticus) following acute exposure: Assessment of some ionoregulatory parameters. Environ. Toxicol., 21(1): 3346. https://doi.org/10.1002/tox.20152

Goksøyr, A. (1991). A semi-quantitative cytochrome P450IA1 ELISA: A simple method for studying the monooxygenase induction response in environmental monitoring and ecotoxicological testing of fish. Sci. Total Environ., 101(3): 255-262. https://doi.org/10.1016/0048-9697(91)90038-G

Guardiola, F.A.; Bahi, A.; Messina, C.M.; Mahdhi, A.; Santulli, A.; Arena, R.; Bakhrouf, A. and Esteban, M.A. (2017). Quality and antioxidant response of gilthead seabream (Sparus aurata L.) to dietary supplements of fenugreek (Trigonella foenum graecum) alone or combined with probiotic strains. Fish Shellfish Immunol., 63: 277-284. https://doi.org/10.1016/j.fsi.2017.02.029

Habig, W.H.; Pabst, M.J. and Jakoby, W.B. (1974). Glutathione-S-transferases: The first enzymatic step in mercapturic acid formation. J. Biol. Chem., 249(22): 7130-7139. http://www.jbc.org/content/249/22/7130.full.html\#ref-list-1

Hassanain, M.A.; Abdel-Rahman, E.H.; Abo-Hegab, S.; Tawfik, M.A.A. and Abbas, W.T. (2007). Induction of cytochrome P450 1A1 as a biomarker of Benzo-apyrene pollution in Egyptian fresh water fish. Pak. J. Biol. Sci., 10(8): 11611169. https://doi.org/10.3923/pjbs.2007.1161.1169

Helal, E.G.E.; El Sayed, R.A.A.; Ebrahiem, S. and Mustafa, M.A. (2018). Effect of Trigonella, Allium Sativum and Their Mixture on Some Physiological Parameters in Hyperthyroidimic Rats. J. Hosp. Med., 71(4): 3049-3055. https://doi.org/10.12816/0046160

Hodek, P.; Trefil, P. and Stiborová, M. (2002). Flavonoids-potent and versatile biologically active compounds interacting with cytochromes P450. Chem. Biol. Interact., 139(1): 1-21. https://doi.org/10.1016/S0009-2797(01)00285-X

Khalesi, M.K.; Abedi, Z.; Behrouzi, S. and Kohestan Eskandari, S. (2017). Haematological, blood biochemical and histopathological effects of sublethal cadmium and lead concentrations in common carp. Bulg. J. Vet. Med., 20(2): 141-150. https://doi.org/10.15547/bjvm.965

Khallaf, E.A.; Galal, M. and Authman, M. (2003). The Biology of Oreochromis niloticus in a Polluted Canal. Ecotoxicology, 12(5): 405-416. https://doi.org/10.1023/A:1026156222685 
Kim, S.-G.; Jee, J.-H. and Kang, J. C. (2004). Cadmium accumulation and elimination in tissues of juvenile olive flounder, Paralichthys olivaceus after sub-chronic cadmium exposure. Environ. Pollut., 127(1): 117-123. https://doi.org/10.1016/S0269-7491(03)00254-9

Le Croizier, G.; Lacroix, C.; Artigaud, S.; Le Floch, S.; Raffray, J.; Penicaud, V.; Coquillé, V.; Autier, J.; Rouget, M.-L.; Le Bayon, N.; Laë, R. and Tito De Morais, L. (2018). Significance of metallothioneins in differential cadmium accumulation kinetics between two marine fish species. Environ. Pollut., 236: 462-476. https://doi.org/10.1016/j.envpol.2018.01.002

Levesque, H.M.; Moon, T.W.; Campbell, P.G.C. and Hontela, A. (2002). Seasonal variation in carbohydrate and lipid metabolism of yellow perch (Perca flavescens) chronically exposed to metals in the field. Aquat. Toxicol., 60(3): 257-267. https://doi.org/10.1016/S0166-445X(02)00012-7

Li, J.; Yan, Y. and Xie, X. (2018). Tissue-Specific Antioxidative Responses and Cadmium Accumulation in Silurus meridionalis Under Chronic Waterborne Cadmium Exposure. Bull. Environ. Contam. Toxicol., 100(4): 485-491. https://doi.org/10.1007/s00128-018-2294-8

Li, X.; Jiang, X.; Sun, J.; Zhu, C.; Li, X.; Tian, L.; Liu, L. and Bai, W. (2017). Cytoprotective effects of dietary flavonoids against cadmium-induced toxicity. Ann. N.Y. Acad. Sci., 1398(1): 5-19. https://doi.org/10.1111/nyas.13344

Maita, M.; Shiomitsu, K. and Ikeda, Y. (1984). Health Assessment by the Climogram of Hemochemical Constituents in Cultured Yellowtail. Bull. Jpn. Soc. Sci. Fish., 51(2): 205-211. https://doi.org/10.2331/suisan.51.205

Marengo, M.; Durieux, E.D.H.; Ternengo, S.; Lejeune, P.; Degrange, E.; Pasqualini, V. and Gobert, S. (2018). Comparison of elemental composition in two wild and cultured marine fish and potential risks to human health. Ecotoxicol. Environ. Saf., 158: 204-212. https://doi.org/10.1016/j.ecoenv.2018.04.034

McCord, J.M. and Fridovich, I. (1969). Superoxide Dismutase: An Enzymic Function For Erythrocuprein (Hemocuprein). J. Biol. Chem., 244(22): 6049-6055. http://www.jbc.org/content/244/22/6049.full.html\#ref-list-1

Mehboob, A.; Khan, N.; Atiq, U.; Iqbal, K.J.; Tayyab, R.; Batool, S.S.; Batool, H.S.; Amjad, S. and Tanveer, M. (2017). Effect of Fenugreek as a Feed Additive on the Growth, Body Composition and Apparent Nutrients Digestibility of Striped Catfish Pangasius hypophthalmus Fry. Pak. J. Zool., 49(6): 2037-2042. http://dx.doi.org/10.17582/journal.pjz/2017.49.6.2037.2042

Messina, C.M.; Faggio, C.; Laudicella, V.A.; Sanfilippo, M.; Trischitta, F. and Santulli, A. (2014). Effect of sodium dodecyl sulfate (SDS) on stress response in the Mediterranean mussel (Mytilus Galloprovincialis): Regulatory volume decrease (Rvd) and modulation of biochemical markers related to oxidative stress. Aquat. Toxicol., 157: 94-100.

https://doi.org/10.1016/j.aquatox.2014.10.001

Min, E.Y. and Kang, J.-C. (2008). Effect of waterborne benomyl on the hematological and antioxidant parameters of the Nile tilapia, Oreochromis niloticus. Pestic. Biochem. Physiol., 92(3): 138-143. https://doi.org/10.1016/j.pestbp.2008.07.007

Mohiseni, M.; Asayesh, S.; Shafieebazarnoie, S.; Mohseni, F.; Moradi, N.; Matouri, M. and Mirzaee, N. (2016). Biochemical Alteration Induced by Cadmium and Lead in Common Carp via an Experimental Food Chain. Iran. J. Toxicol., 10(4): 25-32. http://ijt.arakmu.ac.ir/article-1-471-en.html 
Mostafa, A.A.Z.M.; Ahmad, M.H.; Mousallamy, A. and Samir, A. (2009). Effect of using dried Fenugreek seeds as natural feed additives on growth performance, feed utilization, whole-body composition and entropathogenic Aeromonas hydrophila-challinge of monsex Nile tilapia O. niloticus (L) fingerlings. Aust. J. Basic Appl. Sci., 3(2): 1234-1245.

http://www.ajbasweb.com/old/ajbas/2009/1234-1245.pdf

Mur, R. (2014). Development of the aquaculture value chain in Egypt: Report of the National Innovation Platform Workshop, Cairo, 19-20 February 2014. WorldFish, Cairo, 39 p.

https://cgspace.cgiar.org/bitstream/handle/10568/35247/egypt_IPworlshop_feb2 014.pdf? sequence $=1$

Mushtaq, T.; Javed, M. and Abbas, S. (2017). Peroxidase Activity in Liver and Kidney of Labeo rohita exposed to Zinc Chloride. Pak. J. Zool., 49(6): 23352337. http://dx.doi.org/10.17582/journal.pjz/2017.49.6.sc5

Öner, M.; Atli, G. and Canli, M. (2009). Effects of Metal (Ag, Cd, Cr, Cu, Zn) Exposures on Some Enzymatic and Non-Enzymatic Indicators in the Liver of Oreochromis niloticus. Bull. Environ. Contam. Toxicol., 82(3): 317-321. https://doi.org/10.1007/s00128-008-9577-4

Osman, A.G.M.; Abouelfadl, K.Y.; Abd El Reheem, A.E.B.M.; Mahmoud, U.M.; Kloas, W. and Moustafa, M.A. (2018). Blood Biomarkers in Nile tilapia Oreochromis niloticus niloticus and African Catfish Clarias gariepinus to Evaluate Water Quality of the River Nile. J. FisheriesSciences.com, 12(1): 001015. https://doi.org/10.21767/1307-234X.1000141

Otludìl, B.; Karadede Akin, H. and Ünlü, E. (2017). Effects of sub-lethal exposure of cadmium on histopathology of gills of Nile tilapia, Oreochromis niloticus and the mitigating effects of Cladophora glomerata. Acta Biol. Turc., 30(1): 24-30. http://actabiologicaturcica.com/index.php/abt/article/viewFile/147/126

Parente, T.E.M.; De-Oliveira, A.C.A.X.; Silva, I.B.; Araujo, F.G. and Paumgartten, F.J.R. (2004). Induced alkoxyresorufin-O-dealkylases in tilapias (Oreochromis niloticus) from Guandu river, Rio de Janeiro, Brazil. Chemosphere, 54(11): 1613-1618. https://doi.org/10.1016/j.chemosphere.2003.09.027

Pfaffl, M.W. (2001). A new mathematical model for relative quantification in realtime RT-PCR. Nucleic Acids Res., 29(9 00): 2002-2007. http://dx.doi.org/10.1093/nar/29.9.e45

Porte, C.; Escartín, E.; García De La Parra, L.M.; Biosca, X. and Albaigés, J. (2002). Assessment of coastal pollution by combined determination of chemical and biochemical markers in Mullus barbatus. Mar. Ecol. Prog. Ser., 235: 205-216. https://doi.org/10.3354/Meps235205

Reitman, S. and Frankel, S. (1957). A Colorimetric Method for the Determination of Serum Glutamic Oxalacetic and Glutamic Pyruvic Transaminases. Am. J. Clin. Pathol., 28(1): 56-63. http://dx.doi.org/10.1093/ajcp/28.1.56

Risso-De Faverney, C.; Lafaurie, M.; Girard, J.P. and Rahmani, R. (2000). The nitroxide stable radical tempo prevents metal-induced inhibition of CYP1A1 expression and induction. Toxicol. Lett., 111(3): 219-227. https://doi.org/10.1016/S0378-4274(99)00183-6

Roohi, Z.; Imanpoor, M.R.; Jafari, V. and Taghizadeh, V. (2017). The use of fenugreek seed meal in fish diets: growth performance, haematological and biochemical parameters, survival and stress resistance of common carp (Cyprinus carpio L.). Aquacult. Res., 48(3): 1209-1215. https://doi.org/10.1111/are.12962 
Rusydi, A.F. (2018). Correlation between conductivity and total dissolved solid in various type of water: A review. IOP Conference Series: Earth and Environmental Science 118 012019, IOP Publishing, 7 p. https://doi.org/10.1088/1755-1315/118/1/012019

Sakr, S.A.; Mahran, H.A. and Abo-El-Yazid, S.M. (2009). Fenugreek (Trigonella foenum graecum) ameliorates cyclophosphamide-induced histopathological, histochemical and biochemical changes in the liver of albino mice. Egypt. J. Exp. Biol. (Zool.), 5(0): 331-339. http://www.egyseb.net/ejebz/?mno=189056

Sayed, A.E.-D.H. and Authman, M.M.N. (2018). The protective role of Spirulina platensis to alleviate the Sodium dodecyl sulfate toxic effects in the catfish Clarias gariepinus (Burchell, 1822). Ecotoxicol. Environ. Saf., 163: 136-144. https://doi.org/10.1016/j.ecoenv.2018.07.060

Sayed, A.E.-D.H.; Elbaghdady, H.A.M. and Zahran, E. (2015). Arsenic-induced genotoxicity in Nile tilapia (Orechromis niloticus); the role of Spirulina platensis extract. Environ. Monit. Assess., 187:751, 10 p.

https://doi.org/10.1007/s10661-015-4983-7

Shaalan, M.; El-Mahdy, M.; Saleh, M. and El-Matbouli, M. (2018). Aquaculture in Egypt: Insights on the Current Trends and Future Perspectives for Sustainable Development. Rev. Fish. Sci. Aquac., 26(1): 99-110. https://doi.org/10.1080/23308249.2017.1358696

Shah, A.; Kothari, S. and Parihar, M.S. (2017). Effect of Cadmium on Oxidative Damage in the Liver Of Freshwater Heteropneustes fossilis (Bloch). Int. J. Eng. Technol. Sci. Res., 4(9): 605-609.

http://www.ijetsr.com/images/short_pdf/1504630114_605-609ieteh1091_ijetsr.pdf

Smith, I. (1968). Acrylamide Gel Disc Electrophoresis. Section 1: Techniques of Disc Electrophoresis. In: "Chromatographic and Electrophoretic Techniques. Volume II: Zone Electrophoresis. (Second Edition)." Smith, I. (Ed.). William Heinemann Medical Books Ltd., Pitman Press, Bath, Great Britain, pp. 365-418.

Soliman, N.F. (2017). Aquaculture in Egypt under Changing Climate: Challenges and Opportunities. Alexandria Research Center for Adaptation to Climate Change (ARCA), Alexandria University, ARCA Working Paper, Working Paper No. (4): $40 \mathrm{p}$. http://arca-eg.org/wp-content/uploads/2017/06/Working-Paper-4-Jan.2017.pdf

Srinivasan, K. (2006). Fenugreek (Trigonella foenum-graecum): A Review of Health Beneficial Physiological Effects. Food Rev. Int., 22(2): 203-224. https://doi.org/10.1080/87559120600586315

Sushma, N. and Devasena, T. (2010). Aqueous extract of Trigonella foenum graecum (fenugreek) prevents cypermethrin-induced hepatotoxicity and nephrotoxicity. Hum. Exp. Toxicol., 29(4): 311-319. https://doi.org/10.1177/0960327110361502

Szczerbik, P.; Mikołajczyk, T.; Sokołowska-Mikołajczyk, M.; Socha, M.; Chyb, J. and Epler, P. (2006). Influence of long-term exposure to dietary cadmium on growth, maturation and reproduction of goldfish (subspecies: Prussian carp Carassius auratus gibelio B.). Aquat. Toxicol., 77(2): 126-135.

https://doi.org/10.1016/j.aquatox.2005.11.005

Tietz, N.W.; Finley, P.R. and Pruden, E.L. (1990). Clinical Guide To Laboratory Tests. 2nd ed. WB Saunders Co., Philadelphia, 931 p.

Wang, J.-L.; Meng, X.-L.; Lu, R.-H.; Wu, C.; Luo, Y.-T.; Yan, X.; Li, X.-J.; Kong, X.-H. and Nie, G.-X. (2015). Effects of Rehmannia glutinosa on growth 
performance, immunological parameters and disease resistance to Aeromonas hydrophila in common carp (Cyprinus carpio L.). Aquaculture, 435: 293-300. https://doi.org/10.1016/j.aquaculture.2014.10.004

Xu, X.; Cui, Z.; Wang, X.; Wang, X. and Zhang, S. (2018). Toxicological responses on cytochrome P450 and metabolic transferases in liver of goldfish (Carassius auratus) exposed to lead and paraquat. Ecotoxicol. Environ. Saf., 151: 161-169. https://doi.org/10.1016/j.ecoenv.2017.12.062

Xue, W.-L.; Li, X.-S.; Zhang, J.; Liu, Y.-H.; Wang, Z.-L. and Zhang, R.-J. (2007). Effect of Trigonella foenum-graecum (Fenugreek) Extract on Blood Glucose, Blood Lipid and Hemorheological Properties in Streptozotocin-Induced Diabetic Rats. Asia Pac. J. Clin. Nutr., 16(S1): 422-426. https://doi.org/10.6133/apjen.2007.16.s1.77

Yarru, L.P.; Settivari, R.S.; Gowda, N.K.S.; Antoniou, E.; Ledoux, D.R. and Rottinghaus, G.E. (2009). Effects of turmeric (Curcuma longa) on the expression of hepatic genes associated with biotransformation, antioxidant, and immune systems in broiler chicks fed aflatoxin. Poult. Sci., 88(12): 2620-2627. https://doi.org/10.3382/ps.2009-00204

Y1lmaz, S.; Ergün, S. and Çelik, E.Ş. (2012). Effects of herbal supplements on growth performance of sea bass (Dicentrarchus labrax): Change in body composition and some blood parameters. J. BioSci. Biotech., 1(3): 217-222.

http://www.jbb.uni-plovdiv.bg/documents/27807/33335/jbb_2012-1\%283\%29pages_217-222.pdf/a87e2550-7c94-4e8a-b86b-3bc34feedbd2?version=1.0

Zaki, M.A.; Labib, E.M.; Nour, A.M.; Tonsy, H.D. and Mahmoud, S.H. (2012). Effect Some Medicinal Plants Diets on Mono Sex Nile Tilapia (Oreochromis niloticus), Growth Performance, Feed Utilization and Physiological Parameters. APCBEE Procedia, 4: 220-227. https://doi.org/10.1016/j.apcbee.2012.11.037

Zang, Y. and Bolger, P.M. (2014). Toxic Metals: Cadmium. In: "Encyclopedia of Food Safety. Volume 2: Hazards and Diseases. ." Motarjemi, Y.; Moy, G.G. \& Todd, E.C.D. (Eds.). Elsevier, Inc.: Academic Press, San Diego, CA, USA, pp. 346-348. https://doi.org/10.1016/B978-0-12-378612-8.00202-X

Zhou, S.; Gao, Y.; Jiang, W.; Huang, M.; Xu, A. and Paxton, J.W. (2003). Interactions of Herbs with Cytochrome P450. Drug Metab. Rev., 35(1): 35-98. https://doi.org/10.1081/DMR-120018248

Zhou, Y.; Jing, W.; Dahms, H.-U.; Hwang, J.-S. and Wang, L. (2017). Oxidative damage, ultrastructural alterations and gene expressions of hemocytes in the freshwater crab Sinopotamon henanense exposed to cadmium. Ecotoxicol. Environ. Saf., 138: 130-138. https://doi.org/10.1016/j.ecoenv.2016.12.030

Zirong, X. and Shijun, B. (2007). Effects of waterborne Cd exposure on glutathione metabolism in Nile tilapia (Oreochromis niloticus) liver. Ecotoxicol. Environ. Saf., 67(1): 89-94. https://doi.org/10.1016/j.ecoenv.2006.04.006 